\title{
BMJ Open What can we learn from top-cited articles in inflammatory bowel disease? A bibliometric analysis and assessment of the level of evidence
}

To cite: Azer SA, Azer S. What can we learn from topcited articles in inflammatory bowel disease? A bibliometric analysis and assessment of the level of evidence. BMJ Open 2018:8:e21233. doi:10.1136/ bmjopen-2017-021233

- Prepublication history and additional material for this paper are available online. To view these files, please visit the journal online (http://dx.doi. org/10.1136/bmjopen-2017021233).

Received 29 December 2017 Revised 31 May 2018 Accepted 5 June 2018
Check for updates

${ }^{1}$ College of Medicine, King Saud University, Riyadh, Saudi Arabia ${ }^{2}$ St Vincent Hospital, University of Melbourne, Melbourne, Victoria, Australia

Correspondence to Professor Samy A Azer; azer2000@optusnet.com.au

\section{ABSTRACT}

Background and objectives Despite increasing number of publications in inflammatory bowel disease (IBD), no bibliometric analysis has been conducted to evaluate the significance of highly cited articles. Our objectives were to identify the top-cited articles in IBD, assessing their characteristics and determining the quality of evidence provided by these articles.

Design and outcome measures IBD and related terms were used in searching the Web of Science to identify English language articles. The 50 top-cited articles were analysed by year, journal impact factor (JIF), authorship, females in authorship, institute, country and grants received. The level of evidence was determined using the Oxford Centre for Evidence-Based Medicine guidelines.

Results The number of citations varied from 871 to 3555 with a total of 74638 , and a median $1339.50(\mathrm{IQR}=587)$. No correlations were found between the number of citations and number of years since publication $(r=0.042$, $p=0.771)$, JIF ( $r=0.186, p=0.196)$, number of authors $(r=0.061, p=0.674)$, females in authorship $(r=0.064$, $p=0.661)$, number of institutes $(r=0.076, p=0.602)$, number of countries $(r=0.101, p=0.483)$ or number of grants $(r=-0.015, p=0.915)$. The first authors were from the USA ( $n=24)$, the UK $(n=6)$, Germany $(n=5)$, France $(n=5)$, Belgium $(n=3)$ and Canada $(n=3)$. The levels of evidence were 12 articles at level $1 b, 9$ articles at level 3a and 15 articles at level $3 \mathrm{~b}$ and fewer were at other levels. Conclusions Research papers represented $66 \%$ of articles. The majority of items have reasonably high levels of evidence, which may have contributed to the higher number of citations. The study also shows a gender gap in authorship in this area.

\section{INTRODUCTION}

The number of citations received by an article has been used for several years by universities and grant funding bodies in assessing the quality of research produced by researchers, ranking research performance and in making decisions regarding professional promotion and grant applications. ${ }^{1-4}$ Thomson Reuters gather the names of these authors in the Highly Cited Researchers database, where they are acknowledged for the quality of their

\section{Strengths and limitations of this study}

- More than one method was used in searching the Web of Science to maximise the yield of the search.

- The articles represent a historic perspective on key discoveries in the area of inflammatory bowel disease.

- A number of characteristics including journal impact factor, number of authors, number of females in authorship, number of institutes, number of countries involved and grants received have been studied against citations received.

- The level of evidence for each article has been evaluated.

- The search was limited to articles in the English language, raising the possibility of failing to include top-cited articles in other languages.

work and the size of their research input in a particular area. ${ }^{5}$ Although the number of citations cannot explain why researchers cited a particular paper nor reflect the quality of the research and the outcomes identified in a manuscript, the number of citations and the reputation of contribution to research in a particular field cannot be ignored. This is particularly important when there is a pattern of consistency and progressive input into a discipline over years (a life experience), and a demonstration from publication records and citation history of collaboration with other researchers from other institutes at local and international levels. Hence, the credits given to an author or a group of authors and the impact of the work in a particular area can be proportionally related to the citation records. ${ }^{6}$ The greater the citation history over years, the more influential they are in their specialty. ${ }^{7}$ In this study, we hypothesised that examining the most cited in IBD may provide more insight into the significance of these articles and the level of evidence they present. $^{8}$ Considering the fact that there are over 91000 articles on inflammatory bowel 
disease (IBD) in the literature as per our preliminary search of Web of Science, it is important to consider the characteristics of highly cited articles.

IBD comprises ulcerative colitis (UC) and Crohn's disease $(\mathrm{CD})$; both pursue a relapsing and remitting course over years. While the two diseases share several similarities, they have a number of differences with regard to structures involved, pathogenesis, clinical presentation and management approaches. UC was first reported briefly in mid- $1800,{ }^{9}$ while CD was reported in the Journal of the American Medical Association (JAMA) later by Crohn et al in $1932^{10}$; describing it as a chronic IBD of the ileum. Later, it was discovered that $\mathrm{CD}$ can involve any part of the gastrointestinal tract from the lips to the anal margin but the ileocolonic disease represents the common presentation. Since then both diseases have been extensively researched in their different aspects.

We assumed that these articles may be a cornerstone in IBD, and may enable researchers in understanding a range of aspects related to IBD. Therefore, the bibliometric analysis of these articles including journal impact factor (JIF), authorship, females in authorship, institute, country and grants received may explain key features of a successful or influential article in IBD. The aims of the present research were (1) identify the top-cited articles in IBD, and analyse their characteristics and (2) assess the quality of evidence provided by articles.

\section{METHODS}

\section{Study design}

The Web of Science database was searched for the identification of the top-cited articles and tracking the citation records of each publication. Although Scopus and Google Scholar also provide citation records, it was decided to limit the search to Web of Science database. Compared with other databases, the Web of Science is regularly updated and the 2015 Journal Citation Reports (JCRs) included $>6500$ journals across 150 disciplines. Although Google Scholar database is freely available, it was not used because it is difficult to search, and it cites textbooks, monographs, conference proceedings, as well as non-peer-reviewed publications. ${ }^{11}$ It is also not possible to track the yearly records of citations attracted by each article since publication. Scopus database was not used because it is not extensive in its coverage and its records only go back to $1996 .{ }^{12}$ Furthermore, several other researchers have used Web of Science to identify top-cited articles. ${ }^{13-15}$

To achieve the aims of this study, we planned to identify the highly cited articles in IBD and assess if there were any correlation between the number of citations and any of the parameters characterising these highly cited articles. We also aim to grade each article against the level of evidence hierarchy as per the Oxford Centre for EvidenceBased Medicine (OCEBM-2011 levels of evidence and the accompanying table of evidence glossary). ${ }^{1617}$

\section{Searching the Web of Science database}

On 15 and 16 April 2018, the authors searched the Web of Science database to retrieve top-cited articles in IBD. The search words used were the following: 'Inflammatory bowel disease', 'Ulcerative colitis', 'Crohn's disease', 'IBD', 'Experimental colitis', 'Animal models for Colitis', 'Animal models for inflammatory bowel disease', 'Pathology IBD', 'Pathology UC', Pathology CD', 'Pathogenesis IBD', 'Pathogenesis UC', 'Pathogenesis CD', 'Treatment IBD', 'Treatment UC', 'Treatment CD', 'Investigation IBD' and 'Regional ileitis'. To increase the yield of the search, we used the full terms - inflammatory bowel disease, ulcerative colitis and Crohn's disease for the abbreviations IBD, UC and CD, respectively. These search words were identified from the terminology used in gastroenterology journals and the proceedings of major conferences on IBD and gastroenterology such as the British Society of Gastroenterology, the American Gastroenterological Association, American College of Gastroenterology, Canadian Association of Gastroenterology, Scottish Society of Gastroenterology and Gastroenterological Society of Australia. For each search word, the results were arranged using a link on the Web of Science system, 'sort-by'- 'Time Cited-highest to lowest'. The results showed the articles organised in a descending order with the articles most frequently cited at the top. A copy of the results was printed out for further analysis. The findings from each search word were then arranged on one Excel sheet (Microsoft Excel 2010, Microsoft, Redmond, Washington, USA) in descending order based on the number of citations. Duplicate articles and articles not in the English language were excluded. In addition to the absolute number of citations, we calculated the average citations per year for each article. The average number of citations per year is the ratio calculated from the number of citations obtained by an article divided by the number of years since publication. ${ }^{18}$

Using the above-mentioned search words, we conducted another search of major gastroenterology journals and the 2016 JCR under the category 'Gastroenterology and Hepatology'. This category comprises 76 journals at the time of conducting the search, of these 7 journals were in languages other than English and were not searched. Gastroenterology journals publishing articles not in the English language were excluded because neither the author nor the assistant researchers are competent in the Spanish, Italian or German languages. Since the language recommended by the journal publishing this work is English and its readers are most likely interested in research publications in the English language, we decided not to search these journals.

Interestingly, after identifying the list of top-cited articles in IBD, and again checking these seven non-English journals, none had a paper with a citation higher than the paper ranked number 50 on the list.

These keywords were also used in searching the websites of major general medicine, surgery and research journals including the New England Journal of Medicine, Lancet, the 
British Medical Journal, the Journal of the American Medical Association, Annals of Internal Medicine, Archives of Medicine, PLOS Medicine, Annals of Surgery, Archives of Surgery, British Journal of Surgery, American Journal of Surgical Pathology, Nature, Science, Nature Reviews Cancer, Nature Genetics, Nature Medicine, Cell, Nature Reviews Microbiology, Immunity, Nature Reviews Immunology, Nature Reviews Molecular Cell Biology and Journal of Immunology.

A list identifying the 50 top-cited articles was reviewed again and checked regarding authorship, year of publication, title of the article, journal publishing the work, the JIF at the time of the search, the number of citations and the institution of the first author (see online supplementary appendix 1).

\section{Inclusion and exclusion criteria}

The inclusion criteria were: papers focusing on IBD (UC or $\mathrm{CD}$ ) written in the English language. The exclusion criteria were: (i) articles on IBD in languages other than English, (ii) articles that focused on other diseases and IBD was not the main focus and (iii) studies that focus on other types of colitis and not IBD.

\section{Assessing articles}

The full text of the identified 50 top-cited articles was obtained and a copy was given to each researcher. The following information was collected for each article: (i) the authors' names, the number of authors, their affiliations and the number of females contributing to authorship, (ii) the number of institutes involved in the publication, (iii) the city and country of the origin of the publication, (iv) the total number of citations obtained up to the day of searching the database, and the number of yearly citations since publication, (v) the year of publication and the calculated number of years since publication and (vi) the number of funds/grants stated in the publication and the Web of Science.

We have not used the classification provided by the Web of Science regarding study type because we noted that the Web of Science groups publications as original research, articles, practical guides and reviews and identifies them as articles or reviews. For consistency and the purpose of this study, the top-cited articles were grouped into four types-article, review paper/meta-analysis, report and research. A definition of each type is given in the glossary (see online supplementary appendix 2). Two researchers independently allocated each of the top-cited articles under its type as per the definition given. Any differences between the researchers were discussed in a meeting until a decision was reached.

The topics covered by the top-cited articles were identified by each researcher independently and were discussed in a meeting to harmonise the grouping into a logical, simple and practical way. Articles that covered more than one topic were classified on the basis of the aim of the study and the main outcomes. For other evaluations of an article including the number of authors, the number of females represented in authorship, the number of institutes and countries contributing to the work and the number of grants/funds received, we checked the original article for such details. Institute was defined as the university where an author belonged. If an author belonged to two universities, this was considered to be two different institutes. Regarding the identification of females in the authorship, we noted that several journals use abbreviations of the first and second name rather than the full name. In order to identify the females in these articles, we tried to search the Google database to find the university, personal website of the author, their LinkedIn or ResearchGate accounts. We also tried to identify them by searching the Google Scholar database and identify their account, where we can find other publications under their name and the full first name. In two papers, despite our efforts, we failed to identify the gender of five authors and we contacted the corresponding authors. We received a response from one correspondence, making us unable to identify the gender of three authors in the second paper.

\section{Evaluating the journals}

The publishing journals of the top 50 articles in IBD were identified and evaluated in regard to the following: (i) the $2016 \mathrm{JIF}$ of each journal and (ii) the ranking order of each article in comparison to other articles published in that journal. This was based on the number of citations obtained in comparison to the citation numbers received by other articles published in the journal. For example, an article ranked number one, in its publishing journal, means that the article received the highest number of citations in comparison to all other articles published in that journal. This evaluation aimed at assessing the position order of articles identified among the 50 top-cited articles in IBD in regard to their ranking among other articles published in the journal. Such assessment highlights the significance of the IBD articles among other topics published in gastroenterological journals as well as general medicine journals such as The New England Journal of Medicine, The Lancet, the British Medical Journal, Medicine and top research journals such as Nature, Nature Genetics, Science, Cell and top journals in immunology such as Nature Reviews Immunology (see online supplementary appendix 1).

\section{Assessing level of evidence}

Two researchers independently used the OCEBM2011 levels of evidence and the accompanying table of evidence glossary ${ }^{16}{ }^{17}$ to rank each article regarding level of evidence. In 1998, this hierarchical of evidence was first produced to make the process of finding relevant evidence feasible. Since then the levels have been reviewed and amended, and the version used in this research is the currently available version. This evaluation aimed at identifying the level of evidence of each article and assessing whether the highly cited articles have received higher scores in regard to level of evidence as per the Oxford hierarchy. The assessment required extensive review of each article since quality descriptors 
exist for different types of studies and level of evidence vary depending on therapeutic, prevention, prognostic, diagnostic or prevalence design. ${ }^{13} 14$

\section{Statistical analysis}

Pearson's correlation coefficient $(r)$ was calculated to determine if the high citation numbers obtained was related to the age of the article. Other correlations were between the number of citations and the number of authors, the percentage of females in authorship, the number of institutes, the number of countries involved, the number of grants received and the JIF of the journals in which articles were published. Because of the assumption that researchers usually cite recently published articles, it was decided to compare the mean yearly citations received of articles published before the year 2000 and compare them with those published after the year 2000. All analyses were conducted using SPSS Software (IBM SPSS Statistics Premium V.22.0 for Mac OS-SPSS, Chicago, Illinois, USA) and the results were reported at total, mean, median, IQR and percentage. The inter-rater agreement between evaluators was calculated using the Fleiss kappa scale. ${ }^{19}$

\section{Patient and public involvement}

This study did not involve patients or the public.

\section{RESULTS}

\section{Top-cited papers identified}

The 50 top-cited articles in IBD identified by searching the Web of Science ${ }^{20-69}$ have been summarised in online supplementary appendix 1 . The articles are listed in an order from 1 to 50 with the highest absolute citation number is ranked 1 and the article with the lowest citation ranked 50 as per the day of the search.

Table 1 summarises the year of publication and article type. The articles were published over 57 years (from 1955 to 2012). During the period from 1955 to 1976, only three articles $(6 \%)$ were published. However, the number increased significantly from 1977 to 1994 making a total of $12(24 \%)$ articles. The number of publications increased significantly to $35(70 \%)$ during the years from 1995 to 2012. No correlation was found between the number of citations of these papers and the number of years since published (Pearson's correlation $(\mathrm{r})=0.042, \mathrm{p}=0.771$ ). To assess if there were differences between old articles (published before the year 2000) and those published after the year 2000, it was decided to study the mean number of citations received by top-cited articles in each year after their publications. The year 2000 was taken as a mid-point for comparison because the majority of articles identified were published in the period after the year 1986, and hence the year 2000 could represent such point. As shown from figure $1 \mathrm{~A}$ and $\mathrm{B}$, the mean numbers of citations were higher for articles published after the year 2000 compared with those published before the year 2000. Approximately one-fourth of the top-cited papers

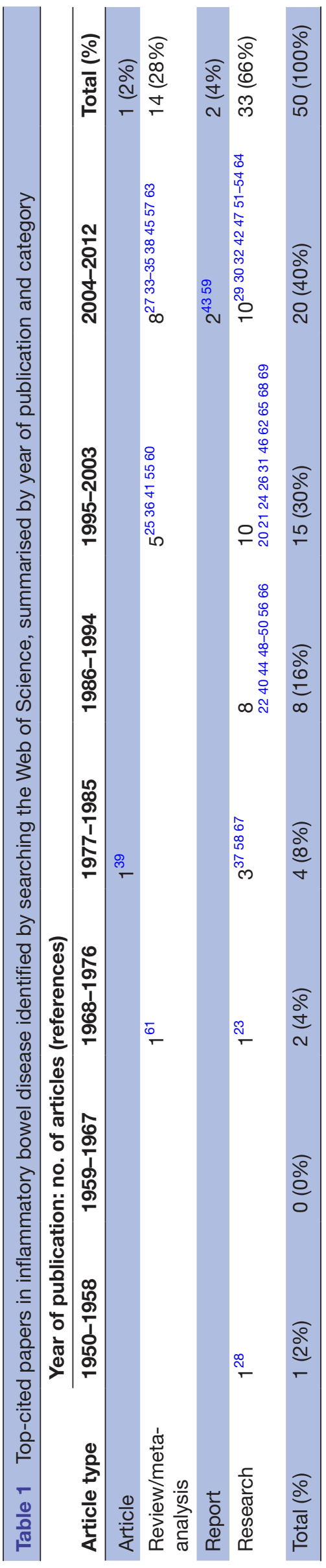




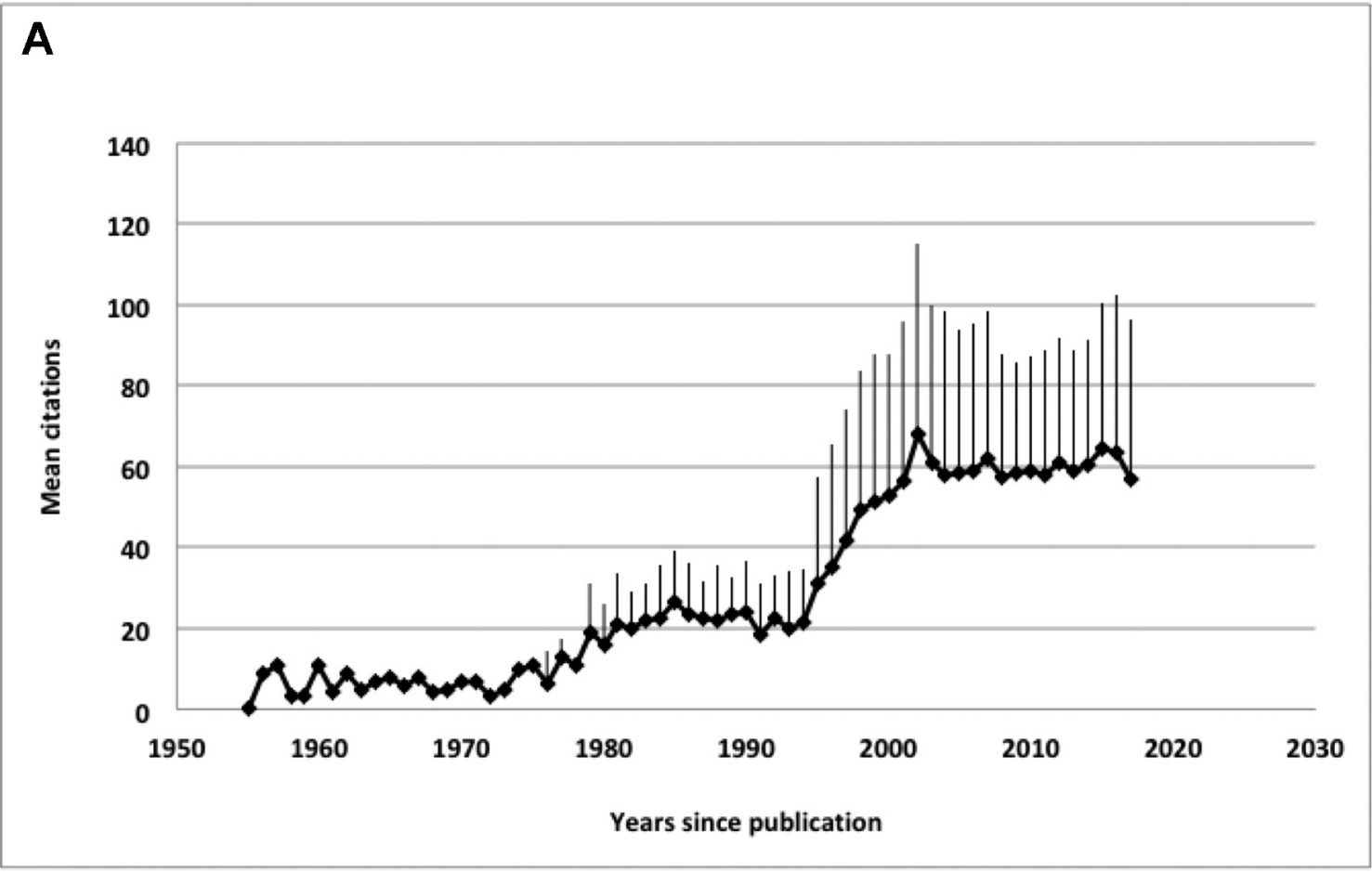

B

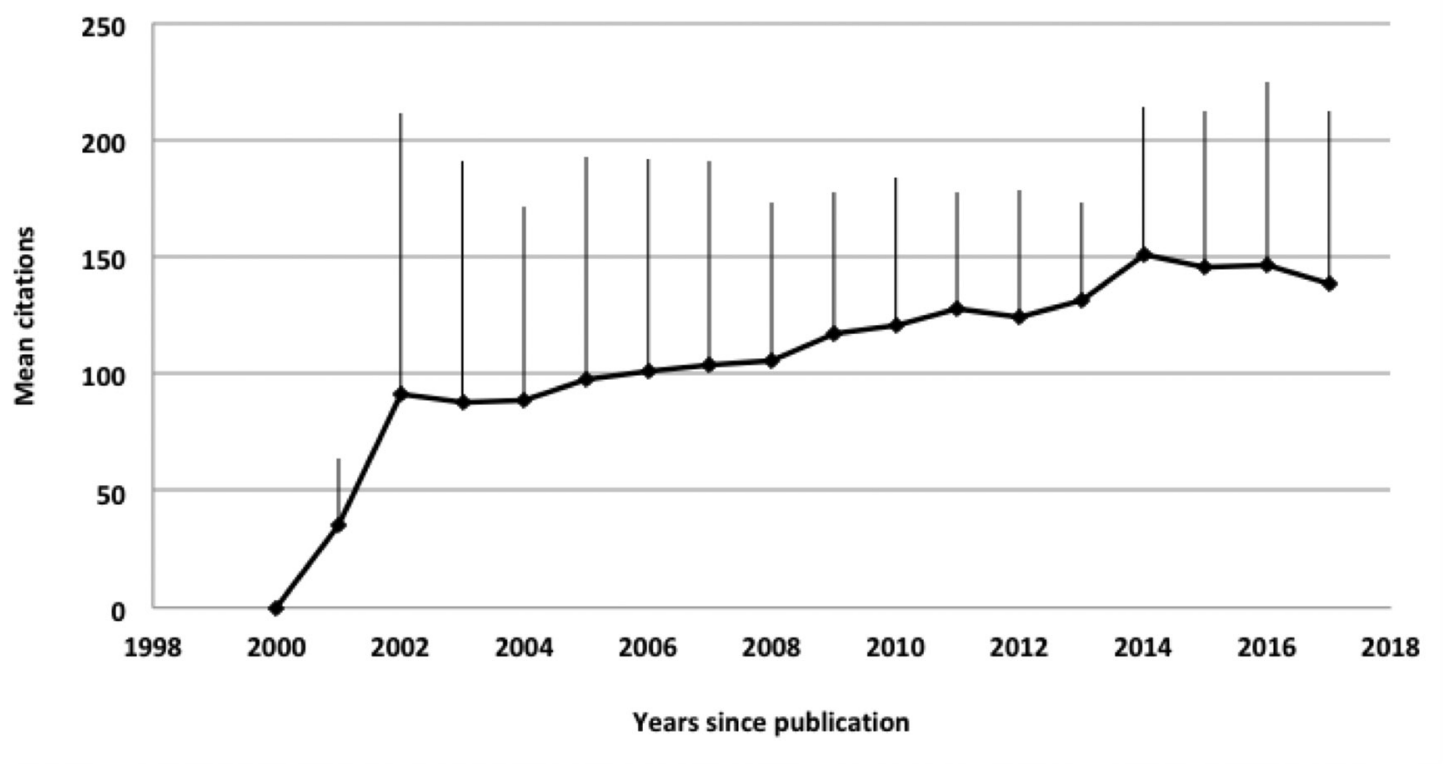

Figure 1 (A) Number of citations of papers published before the year 2000 (mean \pm SD). (B) Number of citations of papers published after the year $2000(\operatorname{mean} \pm S D)$.

were reviews/meta-analysis ( $\mathrm{n}=14,28 \%)$, two-thirds were research papers $(n=33,66 \%)$ and the remaining were an article $(\mathrm{n}=1,2 \%)$ and two reports $(\mathrm{n}=2,4 \%)$.

Table 2 summarises the distribution of IBD topics covered in the top-cited articles. These can be summarised as follows: epidemiology and prevalence $(n=2,4 \%), C D$ genetic susceptibility and NOD2 mutation $(n=6,12 \%)$, animal models $(n=5,10 \%)$, pathogenesis of IBD $(n=15$, $30 \%)$, classification and index of disease activity $(n=5$,
$10 \%)$, risk of developing colorectal cancer $(n=2,4 \%)$, extraintestinal complications $(n=1,2 \%)$, infliximab in CD $(n=6,12 \%)$, corticosteroids in UC $(n=1,2 \%)$, drug treatment and ciclosporin in $\mathrm{UC}(\mathrm{n}=2,4 \%)$, adalimumab in $\mathrm{CD}(\mathrm{n}=1,2 \%), 5$-aminosalicylic acid in $\mathrm{UC}(\mathrm{n}=1,2 \%)$, 6-mercaptopurine in $\mathrm{CD}(\mathrm{n}=1,2 \%)$ and monoclonal antibiotics and antitumour necrosis factor in CD ( $\mathrm{n}=2$, $4 \%$ ). As shown in online supplementary appendix 1,14 $(28 \%)$ were basic research and $19(38 \%)$ were clinical 
Table 2 Top-cited papers in inflammatory bowel disease (IBD) identified by searching the Web of Science, summarised by category and topic

\begin{tabular}{|c|c|c|c|c|c|}
\hline \multirow[b]{2}{*}{ Topics on IBD } & \multicolumn{5}{|c|}{ Category: no. of articles (references) } \\
\hline & Article & $\begin{array}{l}\text { Review/meta- } \\
\text { analysis }\end{array}$ & Report & Research & Total (\%) \\
\hline Epidemiology, prevalence & & $2^{35} 38$ & & & $2(4 \%)$ \\
\hline CD genetic susceptibility and NOD2 mutation & & $2^{3445}$ & & $4^{20215154}$ & $6(12 \%)$ \\
\hline Animal models for IBD & & $1^{60}$ & & $4^{22404448}$ & $5(10 \%)$ \\
\hline Pathogenesis of IBD & & 725273336555763 & & $8^{2932426264-6668}$ & $15(30 \%)$ \\
\hline Classification, index of disease activity & $1^{39}$ & & $2^{4359}$ & $2^{2337}$ & $5(10 \%)$ \\
\hline Risk of developing colorectal cancer & & $1^{41}$ & & $1^{49}$ & $2(4 \%)$ \\
\hline Extraintestinal complications & & $1^{61}$ & & & $1(2 \%)$ \\
\hline Infliximab in CD & & & & $6^{243031464752}$ & $6(12 \%)$ \\
\hline Corticosteroids in UC & & & & $1^{28}$ & $1(2 \%)$ \\
\hline Drug treatment and ciclosporin in UC & & & & $2^{5658}$ & $2(4 \%)$ \\
\hline Adalimumab in CD & & & & $1^{53}$ & $1(2 \%)$ \\
\hline 5-Aminosalicylic acid in UC & & & & $1^{50}$ & $1(2 \%)$ \\
\hline 6-Mercaptopurine in CD & & & & $1^{67}$ & $1(2 \%)$ \\
\hline $\begin{array}{l}\text { Monoclonal antibodies, antitumour necrosis } \\
\text { factor in CD }\end{array}$ & & & & $2^{2669}$ & $2(4 \%)$ \\
\hline Total (\%) & $1(2 \%)$ & $14(28 \%)$ & $2(4 \%)$ & $33(66 \%)$ & $50(100 \%)$ \\
\hline
\end{tabular}

CD, Crohn's disease; UC, ulcerative colitis.

research. The level of evidence is discussed later in the results.

The articles were published in the following journals: New England Journal of Medicine $(\mathrm{n}=12,24 \%)$, Gastroenterology $(\mathrm{n}=12,24 \%)$, Nature $(\mathrm{n}=4,8 \%)$, Nature Genetics $(\mathrm{n}=4,8 \%)$, the Lancet $(\mathrm{n}=2,4 \%)$, Proceedings of the National Academic of Sciences of the United States of America $(\mathrm{n}=2,4 \%)$, Cell $(\mathrm{n}=2,4 \%)$ and Gut $(\mathrm{n}=4,8 \%)$. See table 3 for more details about the journals publishing these articles.

Looking at the ranking of the top-cited articles in IBD in the journals they were published in could provide a better picture about the influence of these articles. This influence would be clearly demonstrated when the journal has a relatively higher JIF. The ranking is based on the number of citations received by an article compared with the number of citations received by other articles that were published in that journal. The article by Best $e t a l^{23}$ is ranked number 4 in the list, and also ranked number 2 among all articles published in Gastroenterology $(2016 \mathrm{JIF}=18.392)$. The article by Eaden $e t a t^{41}$ is ranked number 22 in the list and also ranked number 1 among all articles published in Gut $(2016 \mathrm{JIF}=16.658)$. The ranking of other articles in list and their rankings in the journals in which they were published are shown in online supplementary appendix 1 .

The first authors of the top-cited articles were from the USA $(n=24,48 \%)$, the UK $(n=6,12 \%)$, Germany $(n=5$, $10 \%)$, France $(n=5,10 \%)$, Belgium $(n=3,6 \%)$, Canada $(\mathrm{n}=3,6 \%)$, Japan $(\mathrm{n}=2,4 \%)$, Sweden $(\mathrm{n}=1,2 \%)$ and the Netherlands $(n=1,2 \%)$.
Table 4 summarises the 70 authors who have published two papers or more in the top-cited IBD. Of these, 18 authors were the first author and coauthors of more than two papers in total, all the remaining 52 were coauthors of more than two papers. Top authors were Rutgeers, $\mathrm{P}$ ( $\mathrm{n}=10$ papers), Targan, SR ( $\mathrm{n}=8$ papers), Schreiber, $\mathrm{S}$ ( $\mathrm{n}=7$ papers), Cho, JH ( $\mathrm{n}=7$ papers), Colombel, JF ( $\mathrm{n}=7$ papers), Hanauer, SB ( $n=7$ papers), Silverberg, MS ( $n=6$ papers) and each of the following authors have five papers: Podolsky, DK, Rioux, JD, Daly, MJ, Steinhart, AH, Rotter, JI, Schumm, LP, Taylor, KD, Vermeire, S, Duerr, RH and Regueiro, M.

The leadership of universities and institutes that have contributed to the creation of these publications were Massachusetts General Hospital and Harvard Medical School, Boston, Massachusetts, the USA, Mount Sinai School of Medicine, New York, the USA, Mayo Clinic, Rochester, Minnesota, the USA, Cedars-Sinai Medical Center, Los Angeles, California, the USA, University of Chicago Medical Center, Chicago, Illinois, the USA, University of Pittsburgh, Pittsburgh, Pennsylvania, the USA, University Hospital of Cleveland Case Western Reserve University School of Medicine, Ohio, the USA, Wellcome Trust Centre for Human Genetics, University of Oxford, Roosevelt Drive, Oxford, the UK, Wellcome Trust Sanger Institute, Wellcome Trust Genome Campus, Cambridge, the UK and Institute of Virology and Immunobiology, University of Würzburg, Germany (see online supplementary appendix 1 for more detail). 
Table 3 The journals that published the top-cited inflammatory bowel disease articles included in the study, the journal impact factor (JIF) and the number of papers published and reference number

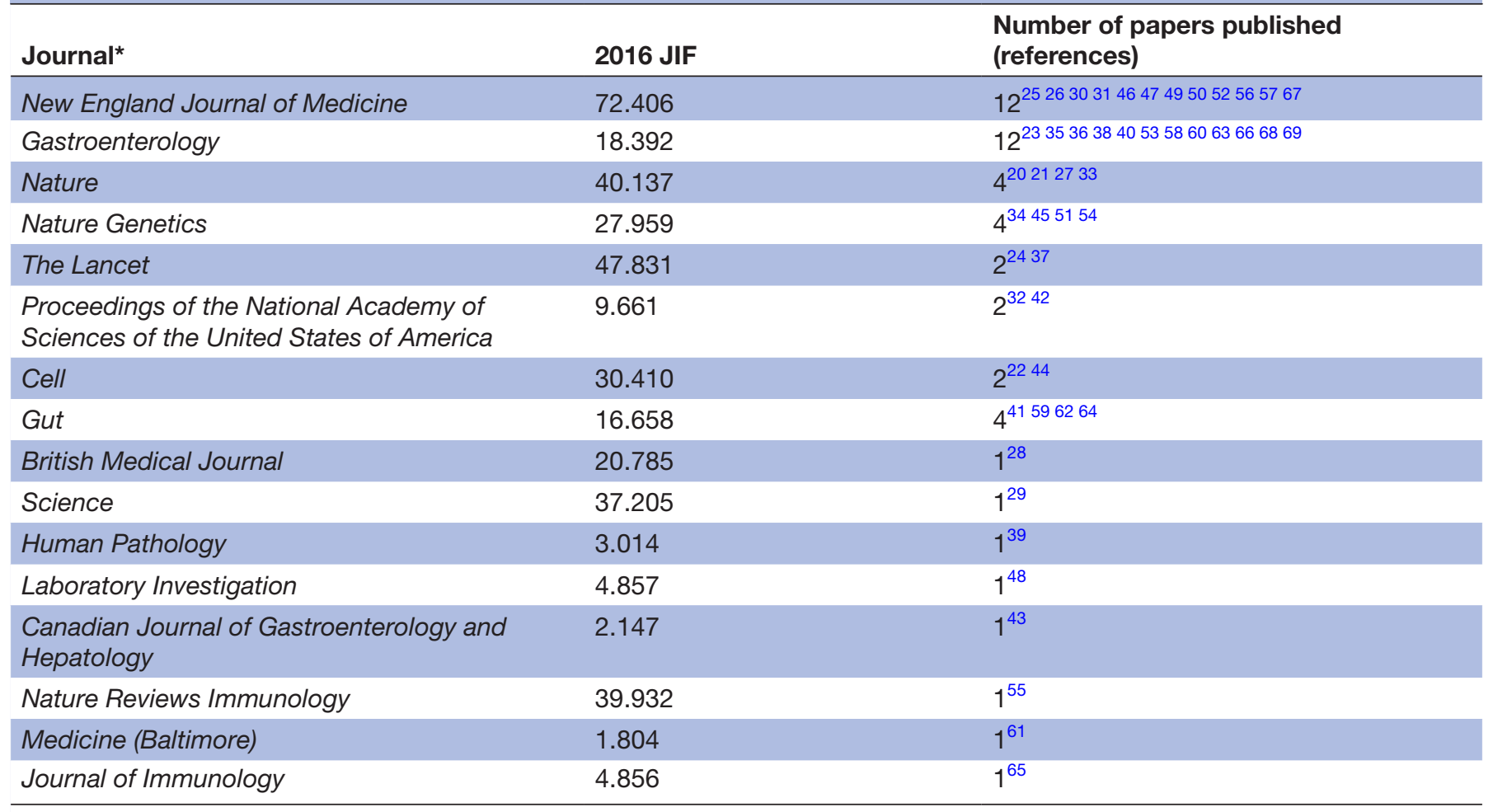

*Gastroenterology-related journals (Gastroenterology and Gut) only published 16 (32\%) articles out of the top highly cited 50 articles.

\section{Characteristics of the top-cited articles}

These articles were created by 667 authors, median 7.0, minimum 1, maximum 106, IQR 9.5; the females in authorship were 111 , median 1.0 , minimum 0 , maximum 20, IQR 2. It is worth mentioning here that it was difficult to identify the gender of some authors in two papers because the full first and middle names were not shown and it was difficult to find more information or clues to make a decision. We contacted the corresponding authors of these two articles; we received information for one article but we had no response from the corresponding author of the second article. Thus, the gender of three authors could not be identified. The number of institutes involved were 436, median 3.0, minimum 1 , maximum 88, IQR 9; the countries involved were 141, median 1.0, minimum 1, maximum 16, IQR 2.75 and the number of grants / funds were 328, median 1.0, minimum 0, maximum 94, IQR 2.75. No correlations were found between the number of citations and the JIF (Pearson's correlation $(r)=0.186 ; p=0.196)$, the number of authors $(\mathrm{r}=0.061 ; \mathrm{p}=0.674)$, number of females in authorship $(\mathrm{r}=0.064 ; \mathrm{p}=0.661)$, the number of institutes involved $(\mathrm{r}=0.076 ; \mathrm{p}=0.602)$, the number of countries involved $(\mathrm{r}=0.101 ; \mathrm{p}=0.483)$ and the number of grants received $(\mathrm{r}=-0.015 ; \mathrm{p}=0.915)$.

\section{Level of evidence}

Table 5 summarises the grading of articles according to the OCEBM. The table shows that most articles were graded at levels $1 \mathrm{~b}$ and $3 \mathrm{a}$ and $3 \mathrm{~b}$ evidence (12 papers had level 1b evidence, 9 papers at level $3 \mathrm{a}$ and 15 papers had level $3 \mathrm{~b}$ evidence). Five articles had a level of evidence of 4 and no article at level 5 . The remaining articles were at levels 1a, 2a, 2b and 2c. The overall agreement between the evaluators was acceptable; Fleiss kappa $=0.8252$; $95 \%$ CI 0.79 to 0.85 .

\section{DISCUSSION}

This study aimed at identifying the characteristics of the top 50 most frequently cited papers in IBD and assessing the quality of evidence provided. The papers covered a number of key topics related to IBD including: epidemiology and prevalence, pathogenesis and genetic susceptibility, animal models, clinical classification and indices of disease activity, risks of developing colorectal cancer, extraintestinal complications and use of infliximab, adalimumab, monoclonal antibodies and antitumour necrosis factor and 6- mercaptopurine in $\mathrm{CD}$, and use of 5-aminosalicylic acid, corticosteroids and ciclosporin in treating UC. While these topics cover key issues related to IBD, topics related to molecular biology, surgical management, patient education, nutritional aspects, radiological and other investigations were not represented in the top-cited articles list. $^{7071}$

The assessment of the characteristics of the top 50 highly cited articles identified in this study reveals the following:

First, the lack of correlations between the number of citations and the number of years since publication may 
Table 4 Authors and coauthors of two or more articles of the top-cited articles in inflammatory bowel disease identified by searching the Web of Science

\begin{tabular}{|c|c|c|c|c|c|}
\hline \multirow[b]{2}{*}{ Author's name* } & \multicolumn{2}{|c|}{ Number (references) } & \multirow{2}{*}{$\begin{array}{l}\text { Author's } \\
\text { name }\end{array}$} & \multicolumn{2}{|c|}{ Number (references) } \\
\hline & First author & Coauthor & & First author & Coauthor \\
\hline Hugot, JP & $1^{20}$ & $2^{3445}$ & Daly, MJ & - & $5^{2933344551}$ \\
\hline Podolsky, DK & $1^{25}$ & $3^{272831}$ & Steinhart, $\mathrm{AH}$ & - & $5^{2934434551}$ \\
\hline Targan, SR & $1^{26}$ & $7^{29313334434551}$ & Griffiths, A & - & $4^{29344551}$ \\
\hline Hanauer, SB & $1^{24}$ & $6^{212630315356}$ & Dassopoulos, $T$ & - & $2^{2934}$ \\
\hline Xavier, RJ & $1^{27}$ & $3^{33} 3451$ & Bitton, A & - & $3^{29} 3334$ \\
\hline Duerr, RH & $1^{29}$ & $4^{21333445}$ & Datta, LW & - & $3^{293451}$ \\
\hline Present, DH & $2^{3167}$ & $3^{26} 3056$ & Kistner, EO & - & $2^{2934}$ \\
\hline Rutgeerts, $\mathrm{P}$ & $1^{30}$ & $9^{24} 26313445-475253$ & Rotter, Jl & - & $5^{2933344551}$ \\
\hline Fiocchi, C & $1^{36}$ & $1^{65}$ & Schumm, LP & - & $5^{2934455152}$ \\
\hline Barrett, JC & $1^{34}$ & $2^{3345}$ & Lee, J & - & $2^{3345}$ \\
\hline Riddell, RH & $1^{39}$ & $2^{4360}$ & Lees, CW & - & $2^{3345}$ \\
\hline Loftus, EV Jr & $1^{35}$ & $1^{43}$ & Sandborn, WJ & - & $3^{304753}$ \\
\hline Franke, A & $1^{45}$ & $2^{3354}$ & Barmada, MM & - & $3^{293451}$ \\
\hline Silverberg, MS & $1^{43}$ & $5^{29} 33344551$ & Nicolae, DL & - & $4^{21293451}$ \\
\hline Rioux, JD & $1^{51}$ & $4^{29333445}$ & Sands, BE & - & $3^{303152}$ \\
\hline Lichtiger, S & $1^{56}$ & $1^{47}$ & Belaiche, J & - & $2^{2034}$ \\
\hline Colombel, JF & $2^{4753}$ & $5^{2024304345}$ & Laukens, D & - & $3^{33} 3445$ \\
\hline Abraham, C & $1^{57}$ & $2^{2933}$ & Lawrance, I & -- & $2^{3345}$ \\
\hline Becktel, JM & - & $2^{2358}$ & Louis, E & - & $3^{33} 3445$ \\
\hline Singleton, JW & - & $2^{2358}$ & Vos, M & - & $3^{33} 3445$ \\
\hline Kern, F Jr & - & $2^{2358}$ & Vermeire, S & - & $5^{3334434546}$ \\
\hline Van Deventer, SJ & - & $4^{26315269}$ & Satsangi, J & - & $4^{33344345}$ \\
\hline Mayer, L & - & $3^{242631}$ & Bernstein, CN & - & $2^{4352}$ \\
\hline Braakman, $T$ & - & $2^{2631}$ & Tremelling, M & - & $2^{3334}$ \\
\hline DeWoody, KL & - & $2^{2631}$ & Mansfield, J & - & $3^{33} 3445$ \\
\hline Schaible, TF & - & $2^{2631}$ & Jewell, D & - & $2^{3443}$ \\
\hline Feagan, BG & - & $3^{243052}$ & Mathew, CG & - & $4^{33344554}$ \\
\hline Lichtenstein, GR & - & $2^{2430}$ & Parkes, M & - & $3^{33} 3445$ \\
\hline Schreiber, S & - & $7^{24334345535468}$ & Georges, M & - & $3^{33} 3445$ \\
\hline Rachmilewitz, D & - & $4^{24304752}$ & Karban, A & - & $2^{4345}$ \\
\hline Wolf, DC & - & $2^{24} 52$ & Gossum, A & - & $2^{3445}$ \\
\hline Olson, A & - & $2^{2430}$ & Franchimont, D & - & $3^{33} 3445$ \\
\hline Taylor, KD & - & $5^{2933} 344551$ & Newman, W & - & $2^{3345}$ \\
\hline Bayless, TM & - & $2^{2145}$ & Regueiro, M & - & $5^{2933344551}$ \\
\hline Cho, JH & - & $7^{21} 293334455157$ & Kornbluth, A & - & $2^{4756}$ \\
\hline
\end{tabular}

*Author's name=family name, abbreviations of first or first and second names.

indicate that the high citations is not caused by ageing of these articles. In fact, only 15 articles $(30 \%)$ were published in the period from 1955 to 1994 (39 years), while the majority, $35(70 \%)$ were published in the last 17 years. No papers were published after 2012. This article also shows that the mean number of citations of articles published before the year 2000 were much lower than those of articles after the year 2000. This may be related to the tendency of researchers to cite recently published research and new findings ${ }^{72}$ and papers that they have read. ${ }^{18}$ Also the number of citations and the papers' age might be attributed to the changes in citation behaviour over time. For example, in the 50s and 60s, the authors used to cite fewer papers compared with what was practised over the last 20 years. ${ }^{73}$ The higher citations have been found to be the strongest predictor of current online 
Table 5 Grading the top-cited articles in inflammatory bowel disease according to the Oxford Centre for Evidence-Based Medicine levels of evidence

\begin{tabular}{|c|c|c|c|}
\hline Level & Domain & Characteristics and description & Articles number (references) \\
\hline \multirow[t]{4}{*}{$1 \mathrm{a}$} & $\begin{array}{l}\text { Therapeutic/prevention, } \\
\text { aetiology/harm }\end{array}$ & $\begin{array}{l}\text { Systematic reviews of RCTs (with consistent } \\
\text { results from individual studies) }\end{array}$ & \multirow[t]{4}{*}{$1^{33}$} \\
\hline & Prognosis & $\begin{array}{l}\text { Systematic reviews with homogeneity of } \\
\text { inception cohort studies }\end{array}$ & \\
\hline & Diagnosis & $\begin{array}{l}\text { Systematic reviews with homogeneity of level } 1 \\
\text { diagnostic studies }\end{array}$ & \\
\hline & $\begin{array}{l}\text { Differential diagnosis/symptom } \\
\text { prevalence study }\end{array}$ & $\begin{array}{l}\text { Systematic reviews with homogeneity of } \\
\text { prospective cohort studies }\end{array}$ & \\
\hline \multirow[t]{4}{*}{$1 b$} & $\begin{array}{l}\text { Therapeutic/prevention, } \\
\text { aetiology/harm }\end{array}$ & Individual RCT (with narrow Cls) & \multirow[t]{4}{*}{$12^{242630475052535658596667}$} \\
\hline & Prognosis & $\begin{array}{l}\text { Individual inception cohort study with }>80 \% \\
\text { follow-up }\end{array}$ & \\
\hline & Diagnosis & $\begin{array}{l}\text { Validating cohort study with good reference } \\
\text { standards }\end{array}$ & \\
\hline & $\begin{array}{l}\text { Differential diagnosis/symptom } \\
\text { prevalence study }\end{array}$ & Prospective cohort study with good follow-up & \\
\hline \multirow[t]{4}{*}{$2 a$} & $\begin{array}{l}\text { Therapeutic/prevention, } \\
\text { aetiology/harm }\end{array}$ & $\begin{array}{l}\text { Systematic review of cohort studies (with } \\
\text { consistent results from individual studies) }\end{array}$ & \multirow[t]{4}{*}{$2^{3463}$} \\
\hline & Prognosis & $\begin{array}{l}\text { Systematic review with homogeneity of either } \\
\text { retrospective cohort studies or untreated } \\
\text { control groups in RCT }\end{array}$ & \\
\hline & Diagnosis & $\begin{array}{l}\text { Systematic review with homogeneity of } \\
\text { level } 2 \text { diagnostic studies }\end{array}$ & \\
\hline & $\begin{array}{l}\text { Differential diagnosis/symptom } \\
\text { prevalence study }\end{array}$ & $\begin{array}{l}\text { Systematic review with homogeneity of } 2 \mathrm{~b} \text { and } \\
\text { better studies }\end{array}$ & \\
\hline \multirow[t]{4}{*}{$2 b$} & $\begin{array}{l}\text { Therapeutic/prevention, } \\
\text { aetiology/harm }\end{array}$ & $\begin{array}{l}\text { Individual cohort study (including low-quality } \\
\text { RCT, eg, }<80 \% \text { follow-up) }\end{array}$ & \multirow[t]{4}{*}{$3^{314649}$} \\
\hline & Prognosis & $\begin{array}{l}\text { Retrospective cohort study or follow-up } \\
\text { untreated control patients in an RCT }\end{array}$ & \\
\hline & Diagnosis & $\begin{array}{l}\text { Exploratory cohort study with good reference } \\
\text { standards }\end{array}$ & \\
\hline & $\begin{array}{l}\text { Differential diagnosis/symptom } \\
\text { prevalence study }\end{array}$ & Retrospective cohort study or poor follow-up & \\
\hline \multirow[t]{4}{*}{$2 c$} & $\begin{array}{l}\text { Therapeutic/prevention, } \\
\text { aetiology/harm }\end{array}$ & Outcome studies (analysis of large registries) & \multirow[t]{4}{*}{$3^{386061}$} \\
\hline & Prognosis & Outcomes research & \\
\hline & Diagnosis & & \\
\hline & $\begin{array}{l}\text { Differential diagnosis/symptom } \\
\text { prevalence study }\end{array}$ & Ecological studies & \\
\hline \multirow[t]{4}{*}{$3 a$} & $\begin{array}{l}\text { Therapeutic/prevention, } \\
\text { aetiology/harm }\end{array}$ & $\begin{array}{l}\text { Systemic reviews of case-control studies (with } \\
\text { consistent results from individual studies) }\end{array}$ & \multirow[t]{4}{*}{$9^{252735364143455557}$} \\
\hline & Prognosis & & \\
\hline & Diagnosis & $\begin{array}{l}\text { Systematic reviews with homogeneity of } 3 \mathrm{~b} \text { and } \\
\text { better studies }\end{array}$ & \\
\hline & $\begin{array}{l}\text { Differential diagnosis/symptom } \\
\text { prevalence study }\end{array}$ & $\begin{array}{l}\text { Systematic reviews with homogeneity of } 3 \mathrm{~b} \text { and } \\
\text { better studies }\end{array}$ & \\
\hline
\end{tabular}




\begin{tabular}{|c|c|c|c|}
\hline Level & Domain & Characteristics and description & Articles number (references) \\
\hline \multirow[t]{4}{*}{$3 b$} & $\begin{array}{l}\text { Therapeutic/prevention, } \\
\text { aetiology/harm }\end{array}$ & Individual case-control study & $15^{20-22282932404244515462646568}$ \\
\hline & Prognosis & & \\
\hline & Diagnosis & $\begin{array}{l}\text { Non-consecutive study, or without consistently } \\
\text { applied reference standards }\end{array}$ & \\
\hline & $\begin{array}{l}\text { Differential diagnosis/symptom } \\
\text { prevalence study }\end{array}$ & $\begin{array}{l}\text { Non-consecutive cohort study or very limited } \\
\text { population }\end{array}$ & \\
\hline \multirow[t]{4}{*}{4} & $\begin{array}{l}\text { Therapeutic/prevention, } \\
\text { aetiology/harm }\end{array}$ & $\begin{array}{l}\text { Case series (and poor quality cohort and case- } \\
\text { control studies) }\end{array}$ & $5^{2337394869}$ \\
\hline & Prognosis & $\begin{array}{l}\text { Case-series (and poor quality prognostic cohort } \\
\text { studies) }\end{array}$ & \\
\hline & Diagnosis & $\begin{array}{l}\text { Case-control study, poor or non-independent } \\
\text { reference standard }\end{array}$ & \\
\hline & $\begin{array}{l}\text { Differential diagnosis/symptom } \\
\text { prevalence study }\end{array}$ & Case-series or superseded reference standards & \\
\hline \multirow[t]{4}{*}{5} & $\begin{array}{l}\text { Therapeutic/prevention, } \\
\text { aetiology/harm }\end{array}$ & $\begin{array}{l}\text { Expert opinion without explicit critical appraisal } \\
\text { or based on physiology, or bench research }\end{array}$ & $0(0)$ \\
\hline & Prognosis & $\begin{array}{l}\text { Expert opinion without explicit critical appraisal } \\
\text { or based on physiology, or bench research }\end{array}$ & \\
\hline & Diagnosis & $\begin{array}{l}\text { Expert opinion without explicit critical appraisal } \\
\text { or based on physiology, or bench research }\end{array}$ & \\
\hline & $\begin{array}{l}\text { Differential diagnosis/symptom } \\
\text { prevalence study }\end{array}$ & $\begin{array}{l}\text { Expert opinion without explicit critical appraisal } \\
\text { or based on physiology, or bench research }\end{array}$ & \\
\hline
\end{tabular}

$\mathrm{RCT}$, randomised controlled trial.

availability after a long time since publication. Therefore, the higher citation could be a protective mechanism for continued availability of a publication despite ageing and hence continuing citation. ${ }^{74}$

Second, the lack of a correlation between the number of citations and the JIF. The JIF has been widely used in ranking and evaluating journals. It stands as a proxy for the relative importance of a journal with its field. ${ }^{75}$ Although the top-cited articles identified were published in journals with high impact factors, the impact factors of some journals were not necessarily the highest in their fields. For example, Laboratory Investigation, Canadian Journal of Gastroenterology and Hepatology, Medicine (Baltimore) and Journal of Immunology had JIFs in the range of 1.804-4.857. With this information in mind one may postulate that the high JIF is not necessarily related to the higher citation numbers received. Two recent works showed that the JIF is not an accurate indicator of citations an average article receives, articles published in low impact factor journals can still be highly cited and vice versa. ${ }^{76} 77$

Third, the study showed negative correlation between the number of citations and the number of authors, the number of female authors or the number of institutes. The number of authors and females in authorship varied from 1 to 106 and from 0 to 20, respectively. Also the number of institutes involved varied from 1 to 88. The question that can be raised in this regard is: are we expecting an increase in number of citations as the number of authors or the number institutes involved increased? The work of García-Aroca $e t a l^{8}$ shows that collaboration between authors increases their impact and increases citation rates. However, they showed that publishing in English in certain journals and collaborating with certain authors and institutes increase the visibility of the manuscripts published on the subject. Hence, it is the quality of collaboration rather than the absolute number of these parameters. Recently, Tanner-Smith and Polanin showed that studies conducted by more established authors (have higher h-indices) and reported in more prestigious journal outlets are more likely to be cited by other scholars, even after controlling for various proxies of study quality. ${ }^{79}$

Although the proportion of women in authorship of original research in the USA in general has significantly increased in the last four decades, women still compose a minority of the authors of original research. ${ }^{80}$ In the field of gastroenterology, the percentage of the US female physician authors of original research in the field has relatively increased over time, yet the senior author position remains lower than expected. ${ }^{81} 82$

Fourth, the study showed no correlation between the number of citations and the number of funds/grants received. This finding is not surprising. Recently, it was shown that too many of the US authors of most influential papers in science do not receive NH funding. ${ }^{83}$ Another group of researchers found no association between grant 
percentile ranking and grant outcome as assessed by number of top $10 \%$ articles per dollar million spent. ${ }^{84}$

The USA, the UK, Germany, France, Belgium and Canada contributed to the majority of these articles. The leadership of universities from these countries in gastrointestinal research particularly IBD is no surprise, top universities identified from this study were Massachusetts General Hospital and Harvard Medical School, Boston, Massachusetts, the USA, Mount Sinai School of Medicine, New York, the USA, Mayo Clinic, Rochester, Minnesota, the USA, Cedars-Sinai Medical Center, Los Angeles, California, the USA, University of Chicago Medical Center, Chicago, Illinois, the USA. Other institutes and research centres that had led these studies are shown in online supplementary appendix 1 .

All articles were published in the English language. The most productive journals were the New England Journal of Medicine and Gastroenterology with a total of 24 articles. Others were Nature, Nature Genetics, the Lancet and Proceedings of the National Academy of Sciences of the United States of America, Cell, Gut, British Medical Journal, Science and Nature Reviews Immunology making a total of 20 articles. While these journals have a relatively high JIF, other journals published one article each and had a relatively low JIF compared with journals included in their categories. For example, Human Pathology listed number 22 under the category of Pathology, and Canadian Journal of Gastroenterology and Hepatology, listed number 74 under the category Gastroenterology and Hepatology. The high level of evidence as outlined in the top-cited articles could be an important contributing factor to the higher number of citations received by these articles. ${ }^{85}$

After the submission of our study we came across the study by Connelly et $a l^{86}$ on top 100 articles on IBD. While they indicated that their findings covered the period between 1955 and 2012, which is consistent with our findings, our study has examined a range of parameters including correlation of citation numbers with JIF, number of years since publication, number of authors, females in authorship, institutes and number of countries and grants, which were not addressed by Connelly et al. Also we have examined the level of evidence of highly cited articles.

\section{CONCLUSIONS}

Our list of top-cited articles in IBD highlights key contributions that based the foundation of research and examination of different aspects of the disease over 57 years. This scholarly contribution came from universities and research centres in the USA, the UK, Germany, France, Belgium and Canada. The findings may be consistent with the concept that it is not the absolute number of collaborators that makes an impact on the citation number or the influence of a publication but rather the quality of such collaboration with regard to the researchers involved, their institutes and the ongoing contribution to the advances of research. The relatively small number of females in the authorship reflects the gender gap and the fact that women still compose a minority of the authors of original research and reviews in gastroenterology. The higher level of evidence demonstrated in most top-cited articles may have contributed to the higher number of citations received by these articles.

Acknowledgements The authors would like to thank Diana Sanad for her assistance and reviewing the manuscript.

Contributors SAA and SA shared equally the different roles and responsibilities to complete the submitted article including the research idea, the search of databases, the evaluation of data collected, the statistical analysis, the interpretation of findings, the creation of tables and figures, writing the manuscript and the approved the final version of the manuscript.

Funding This work was funded by the College of Medicine, Research Center Deanship of Scientific Research, King Saud University, Riyadh, Saudi Arabia.

Competing interests None declared.

Patient consent Not required.

Provenance and peer review Not commissioned; externally peer reviewed.

Data sharing statement No further data available to share.

Open access This is an open access article distributed in accordance with the Creative Commons Attribution Non Commercial (CC BY-NC 4.0) license, which permits others to distribute, remix, adapt, build upon this work non-commercially, and license their derivative works on different terms, provided the original work is properly cited and the use is non-commercial. See: http://creativecommons.org/ licenses/by-nc/4.0/

(c) Article author(s) (or their employer(s) unless otherwise stated in the text of the article) 2018. All rights reserved. No commercial use is permitted unless otherwise expressly granted.

\section{REFERENCES}

1. MacMaster FP, Swansburg R, Rittenbach K. Academic productivity in psychiatry: benchmarks for the H-Index. Acad Psychiatry 2017;41:452-4.

2. Susarla HK, Dhar V, Karimbux NY, et al. Do standard bibliometric measures correlate with academic rank of full-time pediatric dentistry faculty members? J Dent Educ 2017;81:427-32.

3. Milone MT, Bernstein J. On track to professorship? A bibliometric analysis of early scholarly output. Am J Orthop 2016;45:E119-23.

4. Azer SA, Holen A, Wilson I, et al. Impact factor of medical education journals and recently developed indices: Can any of them support academic promotion criteria? J Postgrad Med 2016;62:32-9.

5. Jones AW. Impact of JAT publications 1981-2003: the most prolific authors and the most highly cited articles. J Anal Toxicol 2004;28:541-5.

6. Patsopoulos NA, loannidis JP, Analatos AA. Origin and funding of the most frequently cited papers in medicine: database analysis. BMJ 2006;332:1061-4.

7. Garfield E. Fortnightly review: how can impact factors be improved? BMJ 1996;313:411-3.

8. Azer SA. Exploring the top-cited and most influential articles in medical education. J Contin Educ Health Prof 2016;36(Suppl 1):S32-41.

9. Wilks S. Morbid appearances in the in- testines of Miss Bankes. Med Times Gazette 1859;2:264-5.

10. Crohn BB, Ginzburg L, Oppenheimer GD. Regional ileitis: a pathologic and clinical entity. 1932. Mt Sinai J Med 2000;67:1323-9.

11. Van Noorden R, Maher B, Nuzzo R. The top 100 papers. Nature 2014;514:550-553.

12. Kulkarni AV, Aziz B, Shams I, et al. Comparisons of citations in web of science, scopus, and google scholar for articles published in general medical journals. JAMA 2009;302:1092-6.

13. Powell A, Bevan V, Brown C, et al. Altmetric versus bibliometric perspective regarding publication impact and force. World J Surg 2018.

14. Yi F, Ma J, Ni W, et al. The top cited articles on glioma stem cells in Web of Science. Neural Regen Res 2013;8:1431-8. 
15. Mu Y, Li N, Guan L, et al. Therapies for children with cerebral palsy: a web of science-based literature analysis. Neural Regen Res 2012;7:2632-9.

16. Azer SA. Top-cited articles in problem-based learning: a bibliometric analysis and quality of evidence assessment. J Dent Educ 2017;81:458-78.

17. Oxford Centre for Evidence-based Medicine. Levels of evidence (March 2009). http://www.cebm.net/oxford-centre-evidence-basedmedicine-levels-evidence-march-2009 (accessed 20 May 2017).

18. Azer SA. The top-cited articles in medical education: a bibliometric analysis. Acad Med 2015;90:1147-61.

19. D'Antiga L, Betalli $P$, De Angelis $P$, et al. Interobserver agreement on endoscopic classification of oesophageal varices in children. J Pediatr Gastroenterol Nutr 2015;61:176-81.

20. Hugot JP, Chamaillard M, Zouali H, et al. Association of NOD2 leucine-rich repeat variants with susceptibility to Crohn's disease. Nature 2001;411:599-603.

21. Ogura $\mathrm{Y}$, Bonen DK, Inohara N, et al. A frameshift mutation in NOD2 associated with susceptibility to Crohn's disease. Nature 2001;411:603-6.

22. Kühn R, Löhler J, Rennick D, et al. Interleukin-10-deficient mice develop chronic enterocolitis. Cell 1993;75:263-74.

23. Best WR, Becktel JM, Singleton JW, et al. Development of a Crohn's disease activity index. National Cooperative Crohn's Disease Study. Gastroenterology 1976;70:439-44.

24. Hanauer SB, Feagan BG, Lichtenstein GR, et al. Maintenance infliximab for Crohn's disease: the ACCENT I randomised trial. Lancet 2002;359:1541-9.

25. Podolsky DK. Inflammatory bowel disease. N Engl J Med 2002;347:417-29.

26. Targan SR, Hanauer SB, van Deventer SJ, et al. A short-term study of chimeric monoclonal antibody cA2 to tumor necrosis factor alpha for Crohn's disease. Crohn's Disease cA2 Study Group. N Engl J Med 1997;337:1029-35

27. Xavier RJ, Podolsky DK. Unravelling the pathogenesis of inflammatory bowel disease. Nature 2007;448:427-34.

28. Truelove SC, Witts LJ. Cortisone in ulcerative colitis; final report on a therapeutic trial. Br Med J 1955;2:1041-8.

29. Duerr $\mathrm{RH}$, Taylor KD, Brant SR, et al. A genome-wide association study identifies IL23R as an inflammatory bowel disease gene. Science 2006;314:1461-3.

30. Rutgeerts P, Sandborn WJ, Feagan BG, et al. Infliximab for induction and maintenance therapy for ulcerative colitis. N Engl J Med 2005;353:2462-76.

31. Present $\mathrm{DH}$, Rutgeerts $\mathrm{P}$, Targan $\mathrm{S}$, et al. Infliximab for the treatment of fistulas in patients with Crohn's disease. N Engl J Med 1999;340:1398-405.

32. Frank DN, St Amand AL, Feldman RA, et al. Molecular-phylogenetic characterization of microbial community imbalances in human inflammatory bowel diseases. Proc Natl Acad Sci U S A 2007;104:13780-5.

33. Jostins L, Ripke S, Weersma RK, et al. Host-microbe interactions have shaped the genetic architecture of inflammatory bowel disease. Nature 2012;491:119-24.

34. Barrett JC, Hansoul S, Nicolae DL, et al. Genome-wide association defines more than 30 distinct susceptibility loci for Crohn's disease. Nat Genet 2008;40:955-62.

35. Loftus EV. Clinical epidemiology of inflammatory bowel disease: Incidence, prevalence, and environmental influences. Gastroenterology 2004;126:1504-17.

36. Fiocchi C. Inflammatory bowel disease: etiology and pathogenesis. Gastroenterology 1998;115:182-205.

37. Harvey RF, Bradshaw JM. A simple index of Crohn's-disease activity Lancet 1980;1:514.

38. Molodecky NA, Soon IS, Rabi DM, et al. Increasing incidence and prevalence of the inflammatory bowel diseases with time, based on systematic review. Gastroenterology 2012;142:46-54.

39. Riddell RH, Goldman H, Ransohoff DF, et al. Dysplasia in inflammatory bowel disease: standardized classification with provisional clinical applications. Hum Pathol 1983;14:931-68.

40. Okayasu I, Hatakeyama S, Yamada M, et al. A novel method in the induction of reliable experimental acute and chronic ulcerative colitis in mice. Gastroenterology 1990;98:694-702.

41. Eaden JA, Abrams KR, Mayberry JF. The risk of colorectal cancer in ulcerative colitis: a meta-analysis. Gut 2001;48:526-35.

42. Sokol H, Pigneur B, Watterlot L, et al. Faecalibacterium prausnitzii is an anti-inflammatory commensal bacterium identified by gut microbiota analysis of Crohn disease patients. Proc Natl Acad Sci U $S$ A 2008;105:16731-6.

43. Silverberg MS, Satsangi J, Ahmad T, et al. Toward an integrated clinical, molecular and serological classification of inflammatory bowel disease: report of a Working Party of the 2005 Montreal World Congress of Gastroenterology. Can J Gastroenterol 2005;19(Suppl A):5A-36.

44. Sadlack $B$, Merz $H$, Schorle $H$, et al. Ulcerative colitis-like disease in mice with a disrupted interleukin-2 gene. Cell 1993;75:253-61.

45. Franke A, McGovern DP, Barrett JC, et al. Genome-wide metaanalysis increases to 71 the number of confirmed Crohn's disease susceptibility loci. Nat Genet 2010;42:1118-25.

46. Baert F, Noman M, Vermeire $\mathrm{S}$, et al. Influence of immunogenicity on the long-term efficacy of infliximab in Crohn's disease. $N$ Engl J Med 2003;348:601-8.

47. Colombel JF, Sandborn WJ, Reinisch W, et al. Infliximab, azathioprine, or combination therapy for Crohn's disease. N Engl J Med 2010;362:1383-95.

48. Cooper HS, Murthy SN, Shah RS, et al. Clinicopathologic study of dextran sulfate sodium experimental murine colitis. Lab Invest 1993;69:238-49.

49. Ekbom A, Helmick C, Zack M, et al. Ulcerative colitis and colorectal cancer. A population-based study. N Engl J Med 1990;323:1228-33.

50. Schroeder KW, Tremaine WJ, Ilstrup DM. Coated oral 5-aminosalicylic acid therapy for mildly to moderately active ulcerative colitis. A randomized study. $N$ Engl J Med 1987;317:1625-9.

51. Rioux JD, Xavier RJ, Taylor KD, et al. Genome-wide association study identifies new susceptibility loci for Crohn disease and implicates autophagy in disease pathogenesis. Nat Genet 2007;39:596-604.

52. Sands BE, Anderson FH, Bernstein CN, et al. Infliximab maintenance therapy for fistulizing Crohn's disease. N Engl J Med 2004;350:876-85.

53. Colombel JF, Sandborn WJ, Rutgeerts P, et al. Adalimumab for maintenance of clinical response and remission in patients with Crohn's disease: the CHARM trial. Gastroenterology 2007;132:52-65.

54. Hampe J, Franke A, Rosenstiel P, et al. A genome-wide association scan of nonsynonymous SNPs identifies a susceptibility variant for Crohn disease in ATG16L1. Nat Genet 2007;39:207-11.

55. Bouma G, Strober W. The immunological and genetic basis of inflammatory bowel disease. Nat Rev Immunol 2003;3:521-33.

56. Lichtiger S, Present DH, Kornbluth A, et al. Cyclosporine in severe ulcerative colitis refractory to steroid therapy. N Engl J Med 1994;330:1841-5.

57. Abraham C, Cho JH. Inflammatory bowel disease. N Engl J Med 2009;361:2066-78.

58. Summers RW, Switz DM, Sessions JT, et al. National Cooperative Crohn's Disease Study: results of drug treatment. Gastroenterology 1979;77(4 Pt 2):847-69.

59. Satsangi J, Silverberg MS, Vermeire S, et al. The Montreal classification of inflammatory bowel disease: controversies, consensus, and implications. Gut 2006;55:749-53.

60. Elson CO, Sartor RB, Tennyson GS, et al. Experimental models of inflammatory bowel disease. Gastroenterology 1995;109:1344-67.

61. Greenstein AJ, Janowitz HD, Sachar DB. The extra-intestinal complications of Crohn's disease and ulcerative colitis: a study of 700 patients. Medicine 1976;55:401-12.

62. Fujino S, Andoh A, Bamba S, et al. Increased expression of interleukin 17 in inflammatory bowel disease. Gut 2003;52:65-70.

63. Sartor RB. Microbial influences in inflammatory bowel diseases. Gastroenterology 2008;134:577-94.

64. Manichanh C, Rigottier-Gois L, Bonnaud E, et al. Reduced diversity of faecal microbiota in Crohn's disease revealed by a metagenomic approach. Gut 2006:55:205-11.

65. Fuss IJ, Neurath M, Boirivant M, et al. Disparate CD4+ lamina propria (LP) lymphokine secretion profiles in inflammatory bowel disease. Crohn's disease LP cells manifest increased secretion of IFN-gamma, whereas ulcerative colitis LP cells manifest increased secretion of IL-5. J Immunol 1996;157:1261-70.

66. Rutgeerts P, Geboes K, Vantrappen G, et al. Predictability of the postoperative course of Crohn's disease. Gastroenterology 1990;99:956-63.

67. Present DH, Korelitz BI, Wisch N, et al. Treatment of Crohn's disease with 6-mercaptopurine. A long-term, randomized, double-blind study. N Engl J Med 1980;302:981-7.

68. Swidsinski A, Ladhoff A, Pernthaler A, et al. Mucosal flora in inflammatory bowel disease. Gastroenterology 2002;122:44-54

69. van Dullemen HM, van Deventer SJ, Hommes DW, et al. Treatment of Crohn's disease with anti-tumor necrosis factor chimeric monoclonal antibody (cA2). Gastroenterology 1995;109:129-35.

70. Azer SA. Overview of molecular pathways in inflammatory bowel disease associated with colorectal cancer development. Eur J Gastroenterol Hepatol 2013;25:271-81. 
71. Azer SA, AIOlayan TI, AIGhamdi MA, et al. Inflammatory bowel disease: an evaluation of health information on the internet. World $\mathrm{J}$ Gastroenterol 2017;23:1676-96

72. Börner K, Maru JT, Goldstone RL. The simultaneous evolution of author and paper networks. Proc Natl Acad Sci U S A 2004;101(Suppl 1):5266-73.

73. Sinatra R, Deville P, Szell M, et al. A century of physics. Nat Phys 2015;11:791-6.

74. Wren JD, Georgescu C, Giles CB, et al. Use it or lose it: citations predict the continued online availability of published bioinformatics resources. Nucleic Acids Res 2017;45:3627-33.

75. Shanahan DR. Auto-correlation of journal impact factor for consensus research reporting statements: a cohort study. PeerJ 2016;4:e1887.

76. Royle P, Kandala NB, Barnard K, et al. Bibliometrics of systematic reviews: analysis of citation rates and journal impact factors. Syst Rev 2013;2:74.

77. Falagas ME, Kouranos VD, Michalopoulos A, et al. Comparison of the distribution of citations received by articles published in high, moderate, and low impact factor journals in clinical medicine. Intern Med J 2010;40:587-91.

78. García-Aroca MÁ, Pandiella-Dominique A, Navarro-Suay R, et al. Analysis of Production, Impact, and Scientific Collaboration on Difficult Airway Through the Web of Science and Scopus (19812013). Anesth Analg 2017;124:1886-96.
79. Tanner-Smith EE, Polanin JR. Brief alcohol intervention trials conducted by higher prestige authors and published in higher impact factor journals are cited more frequently. J Clin Epidemiol 2016;75:119-25

80. Jagsi R, Guancial EA, Worobey CC, et al. The "gender gap" in authorship of academic medical literature--a 35-year perspective. $N$ Engl J Med 2006;355:281-7.

81. Long MT, Leszczynski A, Thompson KD, et al. Female authorship in major academic gastroenterology journals: a look over 20 years. Gastrointest Endosc 2015;81:1440-7.

82. Diamond SJ, Thomas CR, Desai S, et al. Gender differences in publication productivity, academic rank, and career duration among U.S. academic gastroenterology faculty. Acad Med 2016;91:1158-63.

83. Nicholson JM, loannidis JP. Research grants: conform and be funded. Nature 2012;492:34-6.

84. Lauer MS, Danthi NS, Kaltman J, et al. Predicting productivity returns on investment: thirty years of peer review, grant funding, and publication of highly cited papers at the national heart, lung, and blood institute. Circ Res 2015;117:239-43.

85. Cheng KL, Dodson TB, Egbert MA, et al. Which factors affect citation rates in the oral and maxillofacial surgery literature? J Oral Maxillofac Surg 2017;75:1313-8.

86. Connelly TM, Devane L, Kelly JC, et al. The 100 classic papers in ulcerative colitis: a bibliometric analysis. Expert Rev Gastroenterol Hepatol 2016;22:1187-95. 